\title{
Hooking Mortality of Smallmouth Bass Caught on Live Minnows and Artificial Spinners
}

\author{
David F. ClaPP ${ }^{1}$ \\ The University of Michigan, School of Natural Resources \\ Ann Arbor, Michigan 48109, USA \\ Richard D. Clark, JR. \\ Institute for Fisheries Research, Michigan Department of Natural Resources \\ Ann Arbor, Michigan 48109, USA
}

\begin{abstract}
The success of no-kill regulations for salmonid fisheries has led to increased interest in applying them to warmwater fisheries. Hooking mortality often makes gear restrictions critical to the success of these regulations. The objective of this study was to determine the probability of death (hooking mortality) for smallmouth bass Micropterus dolomieui caught on live minnows and artificial spinners. We collected 55 wild smallmouth bass from 6.3 to 12.6 in long and tagged them for individual recognition. We divided them into approximately equal groups and released them into artificial stream channels. During four 2-week test periods, we hooked and released fish in one channel using live minnows on a single hook and in the other channel using a spinner with a treble hook. Some fish in each channel were not hooked during the study. Mortality was $11 \%$ for smallmouth bass hooked on minnows, $0 \%$ for those hooked on spinners, and $4 \%$ for those not hooked. Mortality of fish hooked with minnows was significantly greater than mortality of either spinner-hooked or unhooked fish $(P<0.05)$; the latter two mortalities did not differ significantly. Some fish were caught numerous times, and others were never caught. If other types of natural baits and artificial lures also give similar results, it may be necessary to restrict fishing gear to artificial lures to ensure success of no-kill fishing regulations for smallmouth bass.
\end{abstract}

Minimum size limits and gear restrictions (such as artificial lures only) are widely employed to manage sport fisheries. These regulations are often successful, but their benefits can be reduced by mortality of fish caught and released (Wydoski 1977; Pelzman 1978). Hooking mortality has been studied since the early 1930 s, but most such research has been concentrated on salmonids. About $90 \%$ of the hooking mortality references cited in a review by Wydoski (1977) concerned salmonid species, perhaps because of the long sportfishing tradition associated with this family of fishes. However, the popularity of largemouth bass $M i$ cropterus salmoides and smallmouth bass $M$. dolomieui angling appears to be growing. In Michigan, largemouth and smallmouth bass are common in waters near large metropolitan areas, and maintaining or improving the quality of fishing in these waters has received more emphasis lately. Hooking mortality studies have been conducted on largemouth bass (Rutledge and Pritchard 1977; Peltzman 1978), but we could find no references concerning hooking mortality of smallmouth bass.

\footnotetext{
I Present address: Florida Game and Fresh Water Fish Commission, Post Office Box 1903, Eustis, Florida 32727 , USA.
}

Michigan and several other states have adopted 12-in minimum size limits for smallmouth bass. Most smallmouth bass in Michigan do not reach 12 in until they are 4 years old (Latta 1975), so they are subjected to several years of catch-andrelease fishing under current regulations. The effects of hooking mortality on a fishery can be evaluated with existing management models (Clark 1983), but model parameters including the probability that a fish will die from catch and release, must first be measured in a field experiment.

The purpose of this study was to estimate the probability of death (hooking mortality) for smallmouth bass released after they were caught on two common lure types, live minnows and artificial spinners.

\section{Methods}

We collected 55 smallmouth bass from 6.3 to 12.6 in total length in May 1985. Six were taken by $\mathrm{DC}$ electrofishing gear and 37 were taken by angling from the Huron River, Washtenaw County. Twelve were taken with trap nets in Lake St. Clair, Macomb County. We measured total lengths of all smallmouth bass and inserted individually numbered Floy anchor tags at the bases of their dorsal fins. We divided the fish into two similar 
TABLE 1.-Size and method of capture of smallmouth bass released in experimental stream channels. Fish captured by electrofishing and angling were taken from the Huron River; those captured by trap nets were taken in Lake St. Clair. Data are numbers of fish released in the channels.

\begin{tabular}{ccccccccccr}
\hline \multirow{2}{*}{$\begin{array}{c}\text { Length-group } \\
\text { (in) }\end{array}$} & $\begin{array}{c}\text { Electro- } \\
\text { fishing }\end{array}$ & Angling & $\begin{array}{c}\text { Trap } \\
\text { net }\end{array}$ & Total & & $\begin{array}{c}\text { Electro- } \\
\text { fishing }\end{array}$ & Angling & $\begin{array}{c}\text { Trap } \\
\text { net }\end{array}$ & Total \\
\hline $6.0-7.9$ & 1 & 4 & 0 & 5 & 1 & 6 & 0 & 7 \\
$8.0-9.9$ & 0 & 14 & 0 & 14 & 1 & 7 & 0 & 8 \\
$10.0-11.9$ & 1 & 2 & 4 & 7 & & 2 & 4 & 5 & 11 \\
$12.0+$ & 0 & 0 & 1 & 1 & & 0 & 0 & 1 & 1 \\
Total & 2 & 20 & 5 & 27 & & 4 & 17 & 6 & 27 \\
\hline
\end{tabular}

groups with respect to size and method of capture and released them into separate stream channels (Table 1).

Each channel was $15 \mathrm{ft}$ wide $\times 120 \mathrm{ft}$ long. Depth increased from approximately 1 to $4 \mathrm{ft}$ between the upper and lower ends of each channel. Water for the channels was drawn from a reservoir at a depth of $8 \mathrm{ft}$; this kept the channels cold and provided small, natural food items to the fish. Water temperatures remained below $68^{\circ} \mathrm{F}$ during the study (range, $57-64^{\circ} \mathrm{F}$ ). Screens prevented fish larger than about 3 in long from entering or leaving the channels. The channels were designed so they could be drained after each test period and all fish could be recovered.

Fish were held in the channels for 1 week after their initial capture; we then drained the channels to determine if any fish had died due to stress of capture and transport. One of the fish captured by trap nets in Lake St. Clair had died. After draining them, we refilled the stream channels and restocked the remaining fish. We conducted four 2-week tests starting on June 6, 1985. During each test period, we fished in one channel using live fathead minnows Pimephales promelas on a single number- 6 hook and in the other using a Mepps number-1 spinner with a treble hook. For each fish hooked and released, we recorded the tag number and location of hook in the fish. We also recorded the time of day at which angling started and ended for use in determining catch rates. No special care was given to the fish when hooked. They were generally landed in 5-20 s, unhooked by hand, and released back into the channel.

At the end of each test period, the channels were drained and checked for dead fish. We stopped fishing $48 \mathrm{~h}$ before draining the channels to allow at least that amount of time for delayed mortality to occur. Terminal tackle used in each channel was switched after each test period, but the same population of fish remained in each channel throughout the study. We defined the probability of death from catch and release as the proportion of fish dying within a given test period after being hooked and released. When we use the phrase "hooking mortality," we are referring to this probability of death converted into a percentage. For fish that were not hooked, the probability of death was the proportion dying of other causes (natural, handling, tagging, and so on) within each test period. Data from the four test periods were combined and the probabilities of death for minnow-hooked, spinner-hooked, and unhooked smallmouth bass were tested for differences with a chi-square test (comparison of proportions from two independent samples: Snedecor and Cochran 1971).

We measured total length of each fish at the end of the experiment to determine growth increments. We used $t$-tests to compare growth increments of fish in each channel and between hooked and unhooked fish to check for sublethal hooking effects.

We assumed (1) that mortality from hooking did not carry over between test periods, (2) that any mortality of hooked fish observed within a test period occurred as a result of the last recorded hooking event (some fish were hooked more than once during a test period), and (3) that any fish dying after being hooked, died as a result of that hooking (no autopsies were performed to determine actual cause of death).

Based on the first two assumptions, we considered each 2-week period of the study to be a separate hooking mortality trial. They were not separate trials in the strict sense, because we did not use new fish for each trial. Henceforth, we will refer to them as test periods. During each test period, we compared mortality of fish hooked to that of fish not hooked. In so doing, we were able to complete our experiment without the additional fish and stream channel that would have been necessary to maintain a separate control population. We also returned fish to their respective channels after hooking them to investigate possible suble- 
thal effects of multiple hooking events. This would not have been possible if we had removed each hooked fish to a separate enclosure, as was done in some other studies. The main disadvantage of our design was that natural mortality, as well as some behavioral traits, may be different in a separate unfished control population.

\section{Results}

Mortality was $11 \%$ for smallmouth bass hooked on gear baited with minnows, $0 \%$ for those hooked on spinners, and $4 \%$ for those not hooked (Table 2). Mortality of fish hooked with minnows was significantly greater than mortality of either spinner-hooked or unhooked fish $(P<0.05)$. Mortality of fish hooked with spinners was not significantly different from that of unhooked fish.

Site and depth of hook penetration have been shown to influence mortality of fish caught and released. Shetter and Allison (1955) found the two most lethal hooking sites to be the throat and gills, and Warner (1978) found mortality of gill-hooked fish to be significantly greater than that of fish hooked superficially in the mouth. Although we performed no autopsies to determine actual cause of death, three of the four fish dying after being hooked on minnows had been hooked deeply in the esophageal region.

The smallmouth bass grew an average of 0.32 in in length during our study. This was slower than growth of fish in wild populations in our area (Latta 1975). We found no significant difference in the mean growth increment of fish between the two channels. Growth appeared to be inversely related to number of hooking events experienced by individual fish. Mean growth of the fish never

TABLE 2.-Percent mortality for smallmouth bass hooked on minnows and spinners and released compared to mortality of smallmouth bass that were not hooked.

\begin{tabular}{|c|c|c|c|c|c|}
\hline \multirow[b]{2}{*}{ Statistic } & \multicolumn{4}{|c|}{ Test period } & \multirow[b]{2}{*}{ Total } \\
\hline & 1 & 2 & 3 & 4 & \\
\hline \multicolumn{6}{|c|}{ Hooked on minnows } \\
\hline Hooking events & 17 & 7 & 9 & 3 & 36 \\
\hline Deaths & 1 & 1 & 2 & 0 & 4 \\
\hline$\%$ mortality & 6 & 14 & 22 & 0 & 11 \\
\hline \multicolumn{6}{|c|}{ Hooked on spinners } \\
\hline Hooking events & 9 & 15 & 7 & 3 & 34 \\
\hline Deaths & 0 & 0 & 0 & 0 & 0 \\
\hline$\%$ mortality & 0 & 0 & 0 & 0 & 0 \\
\hline \multicolumn{6}{|c|}{ Not hooked } \\
\hline Number & 33 & 32 & 35 & 38 & 138 \\
\hline Deaths & 0 & 2 & 3 & 0 & 5 \\
\hline$\%$ mortality & 0 & 6 & 9 & 0 & 4 \\
\hline
\end{tabular}

TABLE 3.-Size distribution of experimental smallmouth bass and of the subset of fish involved in hooking events. Some fish were hooked several times, and some were never hooked.

\begin{tabular}{cccccc}
\hline \multirow{2}{*}{$\begin{array}{c}\text { Length-group } \\
\text { (in) }\end{array}$} & \multicolumn{2}{c}{ All fish } & & \multicolumn{2}{c}{ Hooking events } \\
\cline { 2 - 3 } \cline { 5 - 6 } & Number & Percent & & Number & Percent \\
\hline $6.0-7.9$ & 12 & 22 & 4 & 6 \\
$8.0-9.9$ & 22 & 41 & & 19 & 27 \\
$10.0-11.9$ & 18 & 33 & & 44 & 63 \\
$12.0+$ & 2 & 4 & & 4 & 4 \\
Total & 54 & 100 & & 70 & 100 \\
\hline
\end{tabular}

hooked, hooked one time, and hooked two or more times was $0.43,0.41$, and 0.08 in, respectively. A regression of growth versus number of hooking events was statistically significant $(P<0.05)$.

The catchability of smallmouth bass was related to either their size, the original method and location of their capture, or both. We could not determine which of these was the most important factor with our data. The mean lengths of fish never hooked, hooked one time, and hooked two or more times were $8.3,9.0$, and 10.5 in, respectively. The 10.0- to 11.9 -in fish were involved in $63 \%$ of all hooking events, but contained only $33 \%$ of the total number of fish (Table 3). The smallmouth bass taken in trap nets from Lake St. Clair were involved in $53 \%$ of the hooking events, but were only $20 \%$ of the total number of fish (Table 4). Because most of the fish in the 10.0- to 11.9in group had been taken in trap nets from Lake St. Clair (Table 1), we could not separate the two factors.

The catchability of individual smallmouth bass varied greatly. Nineteen of the original 54 fish in the experiment were never caught. Ten fish were caught three or more times and accounted for $54 \%$ of all the hooking events. One smallmouth bass was caught nine times and another was caught five times; both survived to the end of the study.

Catch of smallmouth bass per hour of fishing

TABLE 4.-Incidence of smallmouth bass hooking events in relation to the source of the fish and original capture method. Some fish were hooked several times during experiments, and some were never hooked.

\begin{tabular}{|c|c|c|c|c|c|}
\hline \multicolumn{2}{|c|}{ Original capture } & \multicolumn{2}{|c|}{ All fish } & \multicolumn{2}{|c|}{$\begin{array}{c}\text { Hooking } \\
\text { events }\end{array}$} \\
\hline Method & Location & $\begin{array}{c}\text { Num- } \\
\text { ber }\end{array}$ & $\begin{array}{l}\text { Per- } \\
\text { cent }\end{array}$ & $\begin{array}{c}\text { Num- } \\
\text { ber }\end{array}$ & $\begin{array}{l}\text { Per- } \\
\text { cent }\end{array}$ \\
\hline $\begin{array}{l}\text { Electro- } \\
\text { fishing }\end{array}$ & Huron River & 6 & II & 7 & 10 \\
\hline Angling & Huron River & 37 & 69 & 26 & 37 \\
\hline Trap & Lake St. Clair & 11 & 20 & 37 & 53 \\
\hline
\end{tabular}


TABLE 5. - Catch of smallmouth bass per hour for each gear type and 2-week test period in experimental channels.

\begin{tabular}{cllllcc}
\hline & \multicolumn{2}{c}{ Date } & & \multicolumn{3}{c}{ Catch per hour } \\
\cline { 2 - 3 } \cline { 5 - 7 } $\begin{array}{c}\text { Test } \\
\text { period }\end{array}$ & $\begin{array}{l}\text { Started } \\
\text { fshing }\end{array}$ & $\begin{array}{c}\text { Drained } \\
\text { channels }\end{array}$ & & $\begin{array}{c}\text { Min- } \\
\text { nows }\end{array}$ & $\begin{array}{c}\text { Spin- } \\
\text { ners }\end{array}$ & $\begin{array}{c}\text { Com- } \\
\text { bined }\end{array}$ \\
\hline 1 & Jun 3 & Jun 14 & & 2.01 & 0.92 & 1.53 \\
2 & Jun 17 & Jun 28 & & 1.14 & 3.68 & 2.16 \\
3 & Jul 8 & Jul 19 & & 1.99 & 1.69 & 1.84 \\
4 & Jul 22 & Aug 2 & & 0.58 & 0.58 & 0.58 \\
Total & & & & 1.46 & 1.48 & 1.47 \\
\hline
\end{tabular}

varied over the test periods for the two lure types, but total catch per hour over the entire experiment was about the same for each lure type (Table 5). The combined catch per hour for both lure types increased from the first to the second trial, but decreased from the second to the fourth trial. This trend could have been due to a seasonal activity cycle of the fish, or some fish may have learned to avoid capture by the last trial.

\section{Discussion}

Waters in our stream channels were about $9^{\circ} \mathrm{F}$ colder than the natural rivers in our area, and it is possible that hooking mortality would be higher in warmer water, where hooking wounds could be move vulnerable to bacterial or fungal infections. Rutledge and Pritchard (1977) observed a high degree of delayed mortality from secondary infections among largemouth bass hooked in warm Texas ponds. Hunsaker et al. (1970) found that hooking mortality of cutthroat trout Oncorhynchus clarki (formerly Salmo clarki) increased as water temperature increased. The effects of temperature on hooking mortality should be investigated more thoroughly.

The stress of catch and release might have longterm sublethal effects on individual fish. We found that growth was inversely related to the number of times a fish was hooked. Thus, it is possible that heavy fishing pressure under a catch-and-release regulation could directly reduce the growth rate of a fish population. However, we could not determine if hooking events were the cause of reduced growth, or if this relationship resulted because our hooked fish were larger than our unhooked fish. Growth increments in most fish populations decrease with age and size. More research is needed to get a definitive answer on the question of sublethal effects of catch and release.

Some fish were highly vulnerable to angling, whereas others were never caught. The stream channels had smooth mud and gravel bottoms and contained no rocks, logs, or other structures where fish could hide and make themselves more or less vulnerable to the fishing gear. Thus, the degree to which a fish was susceptible to angling appeared to be an individual characteristic. Burkett et al. (1986) obtained similar results for largemouth bass, and they suggested that hook-and-line vulnerability was a heritable trait. Highly vulnerable fish would be harvested very quickly in a fishery with a low minimum size limit, and their removal would reduce the catch rate in the fishery faster than expected based on the number of fish still surviving. On the other hand, a fishery with a high minimum size limit or a catch-and-release regulation might have a higher than expected catch rate because the highly vulnerable fish may be hooked several times. In our experiment, highly vulnerable fish accounted for more than one-half of our total catch.

We think there is potential for improving smallmouth bass fisheries in southern Michigan streams by adopting some of the same kinds of restrictive fishing regulations that are common in trout streams. The results of this study were consistent with similar studies done on salmonids, in that mortality was greater when natural bait was used than when an artificial lure was employed. If other types of natural baits and artificial lures also give similar results, it may be necessary to restrict fishing gear to artificial lures to ensure success of nokill fishing regulations for smallmouth bass.

\section{Acknowledgments}

We thank Frank Hooper of The University of Michigan, School of Natural Resources, and James Gapczynski, Roger Lockwood, and Paul Seelbach of the Institute for Fisheries Research, Michigan Department of Natural Resources, for their help and advice throughout the course of this study.

\section{References}

Burkett, D. P., P. C. Mankin, G. W. Lewis, W. F. Childers, and D. P. Philipp. 1986. Hook-and-line vulnerability and multiple recapture of largemouth bass under a minimum total-length limit of $457 \mathrm{~mm}$. North American Journal of Fisheries Management 6:109-112.

Clark, R. D., Jr. 1983. Potential effects of voluntary catch and release of fish on recreational fisheries. North American Journal of Fisheries Management 3:306-314.

Hunsaker, D., II, L. F. Marnell, and F. P. Sharpe. 1970. Hooking mortality of Yellowstone cutthroat trout. Progressive Fish-Culturist 32:231-235.

Latta, W. C. 1975. Fishing regulations for smallmouth 
bass in Michigan. Michigan Department of Natural Resources, Fisheries Research Report 1834, Ann Arbor.

Pelzman, R. J. 1978. Hooking mortality of juvenile largemouth bass, Micropterus salmoides. California Fish and Game 64:185-188.

Rutledge, W. P., and D. L. Pritchard. 1977. Hooking mortality of largemouth bass captured by artificial lures and natural bait. Pages 109-1 18 in R. A. Barnhart and T. D. Roelofs, editors. Catch-and-release fishing as a management tool. California Cooperative Fishery Research Unit, Arcata.

Shetter, D. S., and L. N. Allison. 1955. Comparison of mortality between fly-hooked and worm-hooked trout in Michigan streams. Michigan Department of Conservation, Institute for Fisheries Research Miscellaneous Publication 9, Ann Arbor.

Snedecor, G. W., and W. G. Cochran. 1971. Statistical methods, 6 th edition. Iowa State University Press, Ames.

Warner, K. 1978. Hooking mortality of lake-dwelling landlocked Atlantic salmon, Salmo salar. Transactions of the American Fisheries Society 107:518522.

Wydoski, R. S. 1977. Relation of hooking mortality and sublethal hooking stress to quality fishery management. Pages 43-87 in R. A. Barnhart and T. D. Roelofs, editors. Catch-and-release fishing as a management tool. California Cooperative Fishery Research Unit, Arcata. 